\title{
A Study of Decision Making Process for the Most Efficient Steaming Speed of Ship
}

\author{
Ayudhia Pangestu Gusti ${ }^{1, a, *}$, Semin $^{1, b}$, A.A.B. Dinariyana ${ }^{1, \mathrm{c}}$ and M. Isa Irawan ${ }^{2, d}$ \\ ${ }^{1}$ Department of Marine Engineering, Institut Teknologi Sepuluh Nopember, Surabaya, Indonesia \\ ${ }^{2}$ Department of Mathematics, Institut Teknologi Sepuluh Nopember, Surabaya, Indonesia \\ a.ayudhia.pg@gmail.com,b.semin@its.ac.id,c.kojex@its.ac.id,d.mii@its.ac.id \\ *ayudhia.pg@gmail.com
}

Keywords: ELECTRE, Extra Slow Steaming, Optimal Ship Speed, Slow Steaming, Super Slow Steaming.

Abstract: Selection of the most efficient steaming speed in shipping word have become an alternative solution for assisting shipping companies in planning a business strategy, reducing the ship operational costs and emission. The application of slow steaming on ships has several advantages, both economically and environmentally. Slow steaming is capable of reducing fuel consumption and exhaust emissions, because these are usually a cubic function of ship speed. Slow steaming can be performed by reducing the service speed of the ship with the aim of minimizing the fuel consumption and ship emissions. There are three different levels of steaming speed known in the shipping sector: slow, extra and super slow steaming. A decision about the most efficient steaming speed should be made by shipping companies considering elements of technical, financial, and environmental aspects. This paper addresses to make a decision as to which one of them will be the most efficient steaming speed for shipping companies. The decision-making method is conducted using Elimination and Choice Expressing Reality (ELECTRE). ELECTRE is a multi-criteria decision making (MCDM) analysis model that is proved to be effective in ranking several decision making problems. The results show that the chosen speed can provide economic and environmental benefits.

\section{Introduction}

Shipping services has become a major international mode of transportation. About $80 \%$ of freight shipments in world trade are using the services of ships [1]. One of the main challenges currently faced is how to reduce the fuel cost of the vessel. It is known that the fuel consumption cost reaches $40 \%-70 \%$ of the total operational cost [2]. In addition, the amount of fuel consumed by the vessel also determines the amount of emitted gas emissions, including nitrogen oxide $(\mathrm{NO})$, carbon dioxide $\left(\mathrm{CO}_{2}\right)$ and sulfur oxide ( $\mathrm{SO}$ ). Globally, international shipping is responsible at least $3 \%$ of $\mathrm{CO}_{2}, 13 \%$ of $\mathrm{NO}_{\mathrm{x}}$, and $12 \%$ of SOx emission [3]. Various ways have been taken to achieve these problems, both in terms of technical and operational aspects. Based on data obtained from ICCT in 2011, speed reduction is the most widely used method to reduce emission and fuel consumption of ship [4]. It is 
known that the speed reduction method is in the first position of $8.5 \%$, continued by hull cleaning of $4.8 \%$, water flow optimization $2.8 \%$ and wind power $2.4 \%$.

Speed reduction otherwise known as slow steaming is a deliberate speed reduction process with the aim of reducing fuel consumption and ship emissions. In addition to slow steaming, there is also extra and super slow steaming.

In this research will be selected the most optimal ship speed among full speed (FS), super slow steaming (SSS), extra slow steaming (ESS) and slow steaming (SS) for shipping company by considering technical (efficiency of the engine and engine fuel consumption), economical (operating cost and ship revenue) and environmental aspects (emission of $\mathrm{SO}_{2}, \mathrm{CO}_{2}$ and $\mathrm{NO}_{\mathrm{x}}$ ). The selection was made to see its effect on the fuel consumption and emissions that produced from the ship. The selection was conducted using Elimination and Choice Expressing Reality (ELECTRE) and mathematical calculations.

\section{Study Literature and Methods}

\subsection{Slow Steaming Overview}

The pioneer of slow steaming use on ships was by Maersk Line around 2008. The first trial ship was a container. The concept of slow steaming has now been adopted by other types of ships including tankers and dry bulk ships [5].

Slow steaming is sailing at lower speeds than is possible, for example the ship sails at 18 knots from a design speed of 22 knots. There are several levels of slow steaming, "slow steaming" for a $15 \%$ reduction in normal operating speed, "extra slow steaming" for $25 \%$ reduction and "super slow steaming" for higher reductions [6].

The positive effect of slow steaming were cutting cost and cutting harmful emission from marine transportation [6]. Ship speed affects the fuel consumption, meanwhile emissions of $\mathrm{SO}_{\mathrm{x}}, \mathrm{NO}_{\mathrm{x}}$ will decrease in line with the use of fuel and $\mathrm{CO}_{2}$ emissions.

On the other hand, sailing at low speeds causes a reduction in the number of cargo ships that can be delivered over a period of time. This may cause loss of income for shipping companies if the demand exceeds the maximum transport performance. In addition, longer travel time affects both the shipper and the customer. This may incur additional capital costs for shippers and customers [7]. Therefore, the selection of speed becomes important to avoid these situation.

Some research on slow steaming has also been done in the maritime field. Zanne et al (2013) conducting research on the slow steaming's benefit from the economic and environmental sides [6]. Emmanuel et al (2013) conducting a research about slow steaming application for a 50,000dwt of product tanker [8]. Dagkinis et al (2015) about slow steaming options investigation using MCDM analysis method. Boersma et al (2015) about ships going slow in reducing NOx emissions [9]. Maloni et al (2013) about the impacts of slow steaming on shippers and ocean carriers [10]. Meyer et al (2012) about slow steaming in container shipping [11].

\subsection{Fuel Consumption and Emission Calculation}

Fuel consumption on ship influenced by the speed of the ship [12]. Some of previous study stated that the daily fuel consumption is a cubic function of speed [13]. Equation 1 is the basic formula for finding fuel consumption. The formula for calculating the fuel consumption of engines refer to (1).

$$
C O F=P \times S F O C \times t
$$


Where, COF is consumption of fuel (gr), $\mathrm{P}$ is engine power $(\mathrm{kW})$, SFOC is Specific Fuel Oil Consumption $(\mathrm{g} / \mathrm{kWh})$ and $\mathrm{t}$ is sailing time (hours).

The calculation of emissions using emissions calculation methods derived from Puget Sound Maritime Air Emission Inventory (PSMAEI) published in 2012 [14]. The calculation of emission refer to (2).

$$
E=\text { Energy } \times E F \times F C F
$$

Where, $E$ is emissions produced by the engine (gr), Energy is energy demand ( $\mathrm{kWh}), E F$ is emission factor $(\mathrm{g} / \mathrm{kWh})$, and FCF is fuel correction factor.

Equation (3) is used to calculate the energy demand as the energy output of the engine over the period of time.

$$
\text { Energy }=M C R \times L F \times A
$$

Where, $M C R$ is the maximum continuous rated engine power $(\mathrm{kW}), L F$ is load factor and $A$ is activity of the ship (hours). The calculation of load factor refer to (4).

$$
\mathrm{LF}=\left(\text { Speed }_{\text {Actual }} / \text { Speed }_{\text {Maximum }}\right)^{3}
$$

Where, Speed $d_{\text {Actual }}$ is the actual speed of the ship (knots) and Speed Maximum is the maximum speed of the ship (knots). The calculation of activity or time in mode refer to (5).

$$
\mathrm{A}=\left(\mathrm{D} / \text { Speed }_{\text {actual }}\right)
$$

Where $\mathrm{D}$ is the distance traveled by ship (nautical miles).

Table 1: Emission factor for main engine $(\mathrm{g} / \mathrm{kwh})$

\begin{tabular}{|l|l|c|l|l|}
\hline \multicolumn{1}{|c|}{ Engine Diesel Type } & \multicolumn{1}{|c|}{ Production year } & NOx & $\mathbf{S O}_{2}$ & $\mathbf{C O}_{2}$ \\
\hline Slow Speed & $\leq 1999$ & 18.1 & 10.5 & 620 \\
\hline Medium Speed & $\leq 1999$ & 14.0 & 11.5 & 683 \\
\hline Slow Speed & $2000-2010$ & 17.0 & 10.5 & 970 \\
\hline Medium Speed & $2000-2010$ & 13.0 & 11.5 & 970 \\
\hline
\end{tabular}

\subsection{Profit Calculation}

The purpose of the profit calculation is to determine the most optimal speed for shipping company to obtain maximum profit. The calculation of profit refer to (6) [11].

$$
P_{V}=I_{V}-C_{V}
$$

Where, $P_{V}$ is profit, $I_{V}$ is vessel income and $C_{V}$ is total operating cost.

\subsubsection{Vessel Income}

Vessel income represent the income received by shipping company from the delivery services activity. The calculation of vessel income refer to (7) [11]. 


$$
I V=\sum P F R, i . F_{S}
$$

Where, $I V$ is the vessel income, $P F R, i$ is the freights rates and $F_{S}$ is the service performance. The calculation of service performance refer to (8).

$$
F s=\text { capeff } . f T
$$

Where, capeff is the effective capacity $(\rho=0.87)$ and $f T$ is the maximum number of roundtrips. The calculation of $f T$ refer to (9).

$$
f T=\mathrm{T}_{\mathrm{O}} /\left(\mathrm{T}_{\mathrm{H}}+\mathrm{T}_{\mathrm{S}}\right)
$$

Where, TO is the operating time (hours), TH is harbor waiting time (hours) and TS is sea (shipping) time.

\subsubsection{Total Operating Cost}

The calculation of total operating cost refer to (10). Operating costs is a combination of consumption cost, port cost and usage cost.

$$
C_{V}=C_{U}+C_{H}+C_{C}
$$

Where, $C_{V}$ is the total operating cost, $C_{U}$ is the usage cost, $C_{H}$ is the harbor cost and $C_{C}$ is the consumption cost.

Consumption cost consist of fuel oil cost and lubricating consumption cost. The calculation of consumption cost refer to (11).

$$
C_{C}=f T \times\left(C_{F}+C_{L}\right)
$$

Where, $C_{C}$ is the consumption cost, $f T$ is the maximum number of roundtrips, $C_{F}$ is the fuel cost and $C_{L}$ is the lubricating cost.

Harbour/ port cost consist of the anchorage and pilotage services, tugboat services and mooring services. The calculation of pilotage cost refer to (12).

$$
P S C=(F r \times \text { movement })+(V r \times G T \times \text { movement })
$$

Where, $P S C$ is pilotage services cost, $F r$ is fixed rates, $V r$ is variable rates and $G T$ is gross tonnage. The calculation of tugboat service cost refer to (13).

$$
T S C=(F r \times \text { unit } \times t)+(V r \times G T \times t)
$$

Where, $T S C$ is tugboat services cost, $F r$ is fixed rates, $V r$ is variable rates, $G T$ is gross tonnage and $\mathrm{t}$ is total time using tug boat (hour). The calculation of mooring service cost refer to (14).

$$
M S C=F r \times G T \times \text { etmal }
$$

Where, $M S C$ is mooring services cost, $F r$ is fixed rates, $G T$ is gross tonnage and 1 etmal similar to 24 hour. 
Usage cost represent cost incurred for insurance, labor and maintenance costs. In this paper, it is assumed that the usage cost is fixed (not dependent on the speed of the vessel).

\subsection{ELECTRE}

ELECTRE is one of the multiple criteria decision-making methods that based on the concept of outranking by using pairwise comparisons of alternatives to each appropriate criterion [15].

ELECTRE methods, usually involve two phase. First, the construction of the outranking relation (concordance and discordance degrees). Second, the exploitation of the outranking relations in order to provide a recommendation [16]. Herewith the following step of ELECTRE process [17].

\section{Step 1. Normalized decision matrix}

Each attribute is converted into a comparable value in this step. The calculation of normalization of the $r_{i j}$ value refer to (15).

$$
r_{i j}=\frac{x_{i j}}{\sqrt{\sum_{i=1}^{m} x_{i j}^{2}}}
$$

The normalization results refer to matrix $R . R$ is a normalized matrix, $m$ represents an alternative, $n$ represent the criterion and $r_{i j}$ is the normalization measurement of the alternative choices of the $i$ th alternative in relation to the $j$-th criterion.

$$
R=\left[\begin{array}{cccc}
r_{11} & r_{12} & \ldots & r_{1 n} \\
r_{21} & r_{22} & \cdots & r_{2 n} \\
\vdots & & & \\
r_{m 1} & r_{m 2} & \cdots & r_{m n}
\end{array}\right]
$$

\section{Step 2. Weighted normalized matrix}

In this step, each column of the matrix $\mathrm{R}$ is multiplied by the weight $\left(w_{j}\right)$ that determined by the decision maker. The calculation of weighted normalized matrix refer to (16).

$$
V=R \times W=\left[\begin{array}{cccc}
w_{1} r_{11} & w_{2} r_{12} & \ldots & w_{n} r_{1 n} \\
w_{1} r_{21} & w_{2} r_{22} & \ldots & w_{n} r_{2 n} \\
\vdots & & & \\
w_{1} r_{m 1} & w_{2} r_{m 2} & \ldots & w_{n} r_{m n}
\end{array}\right]
$$

\section{Step 3. Determine the set of concordances and discordances index}

For each pair of alternatives $\mathrm{k}$ and $\mathrm{l}(\mathrm{k}, \mathrm{l}=1,2,3, \ldots, \mathrm{m}$ and $\mathrm{k} \neq 1)$, set of criteria $\mathrm{J}$ is divided into two subsets.

\section{- Concordance}

The calculation of a criterion in an alternative includes concordance $\left(\mathrm{C}_{k l}\right)$ refer to (17).

- Discordance

$$
C_{k l}=\left\{j, v_{k j} \geq v_{i j}\right\}, \text { for } j=1,2,3, \ldots, n
$$

The calculation of a criterion in an alternative includes discordance $\left(D_{k l}\right)$ refer to (18).

$$
D_{k l}=\left\{j, v_{k j}<v_{i j}\right\}, \text { for } j=1,2,3, \ldots, n
$$




\section{Step 4. Calculate the matrix of concordance and discordance}

The calculation of the matrix of concordance refer to (19) and discordance refer to (20).

$$
\begin{array}{r}
c_{k l}=\sum_{j c_{w}} w_{j} \\
d_{k l}=\frac{\left\{\max \left(v_{m n}-v_{m n-l n}\right)\right\} ; m, n \varepsilon D_{k l}}{\left\{\max \left(v_{m n}-v_{m n-l n}\right)\right\} ; m, n=1,2,3, \ldots}
\end{array}
$$

\section{Step 5. Determine the dominant matrix of concordance and discordances}

Threshold value used for the calculation of the dominant matrix of concordance and discordance.

\section{Step 6. Determine aggregate dominance matrix}

The calculation of the aggregate dominance matrix refer to (21). Where, $e_{k l}$ represent aggregate dominance matrix of Matrix E, $f_{g l}$ and $g_{k l}$ represent matrix elements of matrix F and matrix G.

$$
e_{k l}=f_{k l} \times g_{k l}
$$

\section{Step 7. Elimination of less favorable alternative}

Matrix E gives a sequence of options from each alternative, $e_{k l}=1$ shows the alternative $A_{k}$ is a better choice than $A_{l}$. Thus, the row in the matrix $\mathrm{E}$ which has the least amount of $e_{c l}=1$ can be eliminated. The best alternative is that which dominates other alternatives.

\section{Data}

The data used in this study showed in Table 2. In the case of MV. Meratus M., the ship is designed with a speed of 18.5 knot. MV. Meratus M. sailing from Surabaya with final destination OPL, Singapore.

The fee of anchorage service Tanjung Perak is Rp.112,-/GT. The pilotage services fee of fixed rates is Rp. 225.000,- ship/movement and variable rates Rp. 45,- GT/movement. Tugboat services fee of fixed rates is Rp. 1.443.149,- ship/hour and variable rates Rp. 30,- GT/ship. The mooring services fee for domestic ship is Rp. 116,- GT/etmal. Where, 1 etmal $=24$ hours.

Table 2: Principal dimension of MV. Meratus M.

\begin{tabular}{|l|l|}
\hline Ship's Name & MV. Meratus M. \\
\hline (LoA; B; H; T) & $149.6 \mathrm{~m} ; 23.1 \mathrm{~m} ; 12.8 \mathrm{~m} ; 8.6 \mathrm{~m}$ \\
\hline Design Speed & $18.5 \mathrm{kn}$ \\
\hline \multirow{2}{*}{ Main Eng. (Unit, Type, Power, SFOC, Year) } & $\begin{array}{l}\text { MAN B \& W (1), 7S 50 - MC, 13610 HP, 176, } \\
1995\end{array}$ \\
\hline A/E (Unit, Type, Power) & SULZER (3), 6 S 20 - HW, 1961 HP \\
\hline GT & 11964 \\
\hline Routes & Surabaya - Belawan - OPL- Surabaya \\
\hline Time windows & 316 hours \\
\hline
\end{tabular}




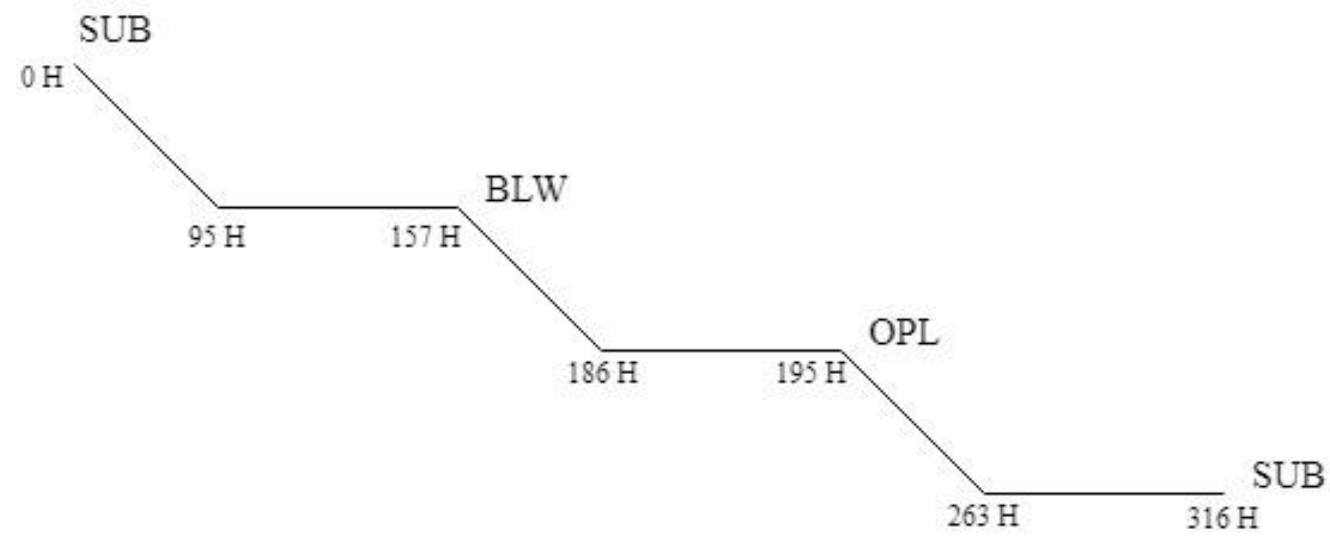

Figure 1: Time windows of MV MERATUS MALINO

Figure. 1 shows the time windows of MV Meratus Malino in one trip from the Port of Surabaya to Belawan, OPL Singapore and back again to the port of Surabaya. Time windows shows the time when the ship will be served on ports. If the ship arrives before the scheduled time, then the ship have to wait until the service time. If the ship arrives after the scheduled time, it may cause service delays for the next ships.

\section{Result and Discussion}

\subsection{Determine the Alternative of the Ship Speed}

The purpose of this research is the selection of the optimal speed on container ship using ELECTRE selection method. Speed is varied into four levels that will be used as alternatives in this selection method. The ship speed is varies into four levels that will be used as alternatives in this selection method.

- SSS

At this stage, the ship speed about $50 \%$ of the engine load. Based on the data obtained, MV. Meratus M sailed at a speed of 11.7 knots.

- ESS

At this stage, the ship speed about $75 \%$ of the engine load. Based on the data obtained, MV. Meratus M sailed at a speed of 16.2 knots.

- SS

At this stage, the ship speed about $85 \%$ of the engine load. Based on the data obtained, MV. Meratus M sailed at a speed of 17.7 knots.

- FS

At this stage, the ship speed about $100 \%$ of the engine load. Based on the data obtained, MV. Meratus M sailed at a speed of 19.7 knots.

\subsection{Determine the Criteria and Sub-Criteria for the Selection of the Optimal Speed}

In this study, the determination of the optimal speed is based on the consideration of three basic component; technical, economic and environmental. These three points represent as criteria consisting of several sub-criteria.

1. Technical and operational

In this criterion, available alternative is assessed from the technical and operational side. 
- Engine efficiency

The lower engine load causes the engine efficiency to decrease as well.

- Fuel consumption of Auxiliary Engine

Increased delivery time due to ship speed reductions will have an impact on the amount of fuel consumed by auxiliary engine.

2. Financial

The purpose of this study is to reduce the fuel consumption that affects the total transportation cost of the ship. The sub criteria on this criteria are as follows.

- Operating Cost

Operating cost include consumption cost, port cost and usage cost.

- Ship Revenue

Revenue earned from shipping activity. Sailing at low speed causes a reduction in the number of cargo ships that can be delivered over a period of time. This may cause loss of income for shipping companies if the demand exceeds the maximum transport performance.

3. Environmental

Aspect that considering the exhaust emissions $\left(\mathrm{CO}_{2}, \mathrm{NO}_{x}, \mathrm{SO}_{2}\right)$ released by ships on the environment.

- Emissions of $\mathrm{CO}_{2}$ and $\mathrm{SO}_{2}$

Reduced along with engine ship energy consumption.

- Emissions of NOx

Decreases along with fuel consumption unless engine ship load becomes very low.

\subsection{Calculate the Value on Each Criteria as the Data Input}

In this section, mathematical calculations are performed on each of the criteria. The calculation result will be used as input data to be processed using ELECTRE. Here are the results of calculations on each of the criteria.

1. Technical and operational

Table 3: Calculation result of engine efficiency and A/E fuel consumption.

\begin{tabular}{|l|l|l|l|l|}
\hline Alternative & SSS & ESS & SS & FS \\
\hline Load & $50 \%$ & $75 \%$ & $85 \%$ & $100 \%$ \\
\hline Power (KW) & 5084 & 7614 & 8641 & 10164 \\
\hline SFOC (g/KWh) MGO & 173 & 164.03 & 163 & 167 \\
\hline Sailing Time (hours) & 139.8 & 122.8 & 117.7 & 111.2 \\
\hline Port Activity (hours) & 125 & 125 & 125 & 125 \\
\hline Total Time (hours) & 264.8 & 247.8 & 242.7 & 236.2 \\
\hline Engine Efficiency (\%) & 92.6 & 93.5 & 93.6 & 94.0 \\
\hline Fuel Con. (ton) & 124 & 168 & 178 & 202 \\
\hline A/E Fuel Con. (ton) & 84 & 88 & 89 & 91 \\
\hline
\end{tabular}

This criterion consists of two sub criteria. Table 3 shows the calculations for the sub-criteria for engine efficiency and fuel consumption of the auxiliary engines in each alternative. From the calculation result, the biggest efficiency is $91 \%$, when the ship is sailing using full speed and minimum fuel consumption of auxiliary engine is at super slow steaming condition. 


\section{Financial}

This criterion consists of two sub criteria. Table 6 shows the calculation results for the sub-criteria of operating cost and ship revenue in each alternative. From the calculations as shown in Table 4, at the speed of super slow steaming shows that operational cost and ship revenue is the lowest compared with other alternatives.

Table 4: Calculation result of operating cost and ship revenue

\begin{tabular}{|c|c|c|}
\hline Alternative & Operational Cost & Ship Revenue \\
\hline SSS & $R p 968,915,031$ & $\operatorname{Rp~} 4,039,931,825.65$ \\
\hline ESS & $\operatorname{Rp~} 1,296,291,018$ & $\operatorname{Rp~3,712,555,838.72~}$ \\
\hline SS & $\operatorname{Rp~} 1,370,325,802$ & $\operatorname{Rp~3,638,521,054.84~}$ \\
\hline FS & $\operatorname{Rp~} 1,548,907,083$ & $\operatorname{Rp~3,459,939,774.41~}$ \\
\hline
\end{tabular}

\section{Environmental}

This criterion consists of three sub criteria based on the emissions generated by the ship. Table 5 shows the results of the emission calculations for each alternative. From these calculations, the lowest emission levels is at the super slow steaming condition. This shows that ship speed affects the ship's emission level.

Table 5: Calculation result of emissions

\begin{tabular}{|l|l|l|l|l|}
\hline Alternative & SSS & ESS & SS & FS \\
\hline Power (KW) & 5084 & 7614 & 8641 & 10164 \\
\hline Engine Speed (RPM) & 74.00 & 103.10 & 112.30 & 127.00 \\
\hline Speed (knot) & 15.9 & 18.1 & 18.9 & 20.0 \\
\hline LF & 0.20 & 0.54 & 0.69 & 1.00 \\
\hline Activity (hours) & 264.8 & 247.8 & 242.7 & 236.2 \\
\hline Sailing Time (hours) & 139.8 & 122.8 & 117.7 & 111.2 \\
\hline Energy (kWh) & 203413.83 & 591351.39 & 796210.71 & 1197742.07 \\
\hline NOx (ton) & 11.5 & 23.8 & 30.1 & 40.8 \\
\hline SO2 $_{2}$ (ton) & 3.9 & 8.2 & 10.3 & 14.0 \\
\hline CO$_{2}$ (ton) & 419.9 & 868.6 & 1096.9 & 1488.5 \\
\hline
\end{tabular}

\subsection{ELECTRE Implementation for the Selection of Optimal Speed}

In this section, the calculations from the previous section will be used as input data in the process of selection. The input data also comes from the questionnaire given to the expert in this field as shown in Table 6. From the results of elections using ELECTRE, obtained the following results.

Table 6: Matrix of concordance

\begin{tabular}{|l|c|c|c|c|}
\hline Alternative & SSS & ES & SS & FS \\
\hline Engine efficiency & 5 & 4 & 4 & 3 \\
\hline A/E Fuel Consumption & 4 & 4 & 4 & 3 \\
\hline Operational cost & 3 & 4 & 5 & 5 \\
\hline Ship Revenue & 4 & 4 & 4 & 3 \\
\hline CO$_{2}$ & 3 & 4 & 5 & 5 \\
\hline NOx & 3 & 4 & 5 & 4 \\
\hline SOx & 3 & 4 & 5 & 5 \\
\hline
\end{tabular}


- Concordance

Table 7 shows the concordance matrix at the process of selection using ELECTRE.

Table 7: Matrix of concordance

\begin{tabular}{|l|l|l|l|l|}
\hline & Altern. 1 & Altern. 2 & Altern. 3 & Altern. 4 \\
\hline Altern. 1 & 0.00 & 27.00 & 27.00 & 20.00 \\
\hline Altern. 2 & 11.00 & 0.00 & 31.00 & 20.00 \\
\hline Altern. 3 & 11.00 & 11.00 & 0.00 & 15.00 \\
\hline Altern. 4 & 11.00 & 16.00 & 31.00 & 0.00 \\
\hline
\end{tabular}

- Discordance

Table 8 shows the discordance matrix at the process of selection using ELECTRE.

Table 8: Matrix of discordance

\begin{tabular}{|l|l|l|l|l|}
\hline & Altern. 1 & Altern. 2 & Altern. 3 & Altern. 4 \\
\hline Altern. 1 & 0.00 & 0.80 & 0.40 & 0.85 \\
\hline Altern. 2 & 1.00 & 0.00 & 0.00 & 0.92 \\
\hline Altern. 3 & 1.00 & 1.00 & 0.00 & 1.00 \\
\hline Altern. 4 & 1.00 & 1.00 & 0.00 & 0.00 \\
\hline
\end{tabular}

- Dominant Matrix

Determining the dominant matrix requires a threshold value. The resulting threshold value of concordance is 17.50 and threshold value of discordance is 0.70 . Table 9 shows the matrix dominant of concordance and Table 10 shows the matrix dominant of discordance.

Table 9: Dominant Matrix of concordance

\begin{tabular}{|l|l|l|l|l|}
\hline & Altern. 1 & Altern. 2 & Altern. 3 & Altern. 4 \\
\hline Altern. 1 & 0.00 & 1.00 & 1.00 & 1.00 \\
\hline Altern. 2 & 0.00 & 0.00 & 1.00 & 1.00 \\
\hline Altern. 3 & 0.00 & 0.00 & 0.00 & 0.00 \\
\hline Altern. 4 & 0.00 & 0.00 & 1.00 & 0.00 \\
\hline
\end{tabular}

Table 10: Dominant Matrix of discordance

\begin{tabular}{|l|l|l|l|l|}
\hline & Altern. 1 & Altern. 2 & Altern. 3 & Altern. 4 \\
\hline Altern. 1 & 0.00 & 1.00 & 0.00 & 1.00 \\
\hline Altern. 2 & 1.00 & 0.00 & 0.00 & 1.00 \\
\hline Altern. 3 & 1.00 & 1.00 & 0.00 & 1.00 \\
\hline Altern. 4 & 1.00 & 1.00 & 0.00 & 0.00 \\
\hline
\end{tabular}

- Elimination less favourable alternative

The final stage of selections using ELECTRE is to eliminate less favourable alternatives. Table 11 shows selected alternatives. 
Table 11: Selected alternatives

\begin{tabular}{|l|c|}
\hline Alternative & Value \\
\hline Alternative 1 & 2.00 \\
\hline Alternative 2 & 1.00 \\
\hline Alternative 3 & 0.00 \\
\hline Alternative 4 & 0.00 \\
\hline
\end{tabular}

The selection process using ELECTRE show that super slow steaming is the most optimal speed to be considered in terms of technical, cost and the environment for shipping company. Super slow steaming causes a reduction in revenue for the shipping company, but can reduce transportation costs and exhaust emissions without passing through a given time windows.

\section{Conclusions}

Speed reduction otherwise known as slow steaming is a deliberate speed reduction process with the aim of reducing fuel consumption and ship emissions. While the negative impact is increasing the shipping time and causes reduction in the number of cargo ships that can be delivered over a period of time. Sailing at very low speed will also affect the ship engine performance.

In addition to slow steaming, there is also extra and super slow steaming. In this research will be selected the most optimal ship speed among the steaming speed for shipping company by considering technical, economical and environmental aspects. The selection was made to see its effect on the reduction of fuel consumption and emissions of the ship. The selection was conducted using Elimination and Choice Expressing Reality (ELECTRE) and mathematical calculations.

From the selection process, the result shows that super slow steaming is chosen as the most optimal speed compared to the others if considered from the technical side, financial and environmental. Super slow steaming causes a reduction in revenue for the shipping company, but can reduce transportation costs and exhaust emissions without passing through a given time windows.

\section{Acknowledgements}

In this paper the authors very express the acknowledgement to the Department of Marine Engineering, Faculty of Marine Technology, Institut Teknologi Sepuluh Nopember, Surabaya, Indonesia for the support of this research. This research would not have been possible without the financial support of Doctoral Program Master's Degree Superior (PMDSU) Scholarship, funded by Indonesian Directorate General of Higher Education (DIKTI)

\section{References}

[1] Limited, I.G., Global Trade Atlas, 2016.

[2] Papadakis, N.A. and A.N. Perakis, A Nonlinear Approach to the Multiorigin, Multidestination Fleet Deployment Problem. Naval Research Logistics, 1989. 36(4): p. 515-528.

[3] Gusti, A.P. and Semin, Speed Optimization Model for Reducing Fuel Consumption Based on Shipping Log Data. International Journal of Mechanical, Aerospace, Industrial, Mechatronic and Manufacturing Engineering, 2017. 122: p. $339-342$.

[4] (ICCT), T.I.C.o.C.T., Reducing Greenhouse Gas Emissions from Ships : Cost Effectiveness of Available Options, 2011: Washington. p. 4-8.

[5] Sanguri, M., The Guide to Slow Steaming on Ships, R. Kantharia, Editor 2012, Marine Insight.

[6] Zanne, M., M. Počuča, and P. Bajec, Environmental and Economic Benefits of Slow Steaming. Transactions on Maritime Science, 2013. 02: p. 123-127. 
[7] Dagkinis, I. and N. Nikitakos, Slow Steaming Options Investigation Using Multi Criteria Decision Analysis Method, in ECONSHIP 20152015: Greece.

[8] Emmanuel, A.N., et al., Slow steaming application for a 50,000dwt product tanker: Trade-off between optimal speed and freight rate. Regional Maritime University Journal, 2013. 3(37-49).

[9] Boersma, K., G.C.M. Vinken, and J. Tournadre, Ships going slow in reducing their NOx emissions: changes in 2005-2012 ship exhaust inferred from satellite measurements over Europe. Environmental Research Letters, 2015. 10: p. 1-10.

[10] Maloni, M., J.A. Paul, and D.M. Gligor, Slow steaming impacts on ocean carriers and shippers. Maritime Economics \& Logistics, 2013. 15: p. 151-171.

[11] Meyer, J., R. Stahlbock, and S. Voß, Slow Steaming in Container Shipping, in 45th Hawaii International Conference on System Sciences2012.

[12] Semin and A.P. Gusti, The Effect of Ship Speed on Fuel Consumption: A Review. Journal of Engineering and Applied Sciences, 2017. 12(22): p. 6052-6056.

[13] Wang, S., Fundamental properties and pseudo-polynomial-time algorithm for network container ship sailing speed optimization. European Journal of Operational Research, 2016. 250: p. 46-55.

[14] Agrawal, A., et al., 2011 Puget Sound Maritime Air Emissions Inventory, 2012, Starcrest Consulting Group, LLC: Washington.

[15] Yu, X., et al., ELECTRE methods in prioritized MCDM environment. Information Sciences, 2018. 424: p. $301-316$.

[16] Ishizaka, A. and P. Nemery, Assigning machinestoincomparablemaintenancestrategies with ELECTRE-SORT. Omega 2014. 47: p. 45-59.

[17] Setiawan, F., F. Indriani, and Muliadi, Implementasi Metode Electre Pada Sistem Pendukung Keputusan SNMPTN Jalur Undangan. Kumpulan Jurnal Ilmu Komputer (KLIK), 2015. 02(02): p. 88-101. 